L.Dikan,

PhD in Economics, Professor of Accounting and Business Consulting

Simon Kuznets Kharkiv National University of Economics

ORCID ID: 0000-0003-4107-3508

I. Shevchenko,

$P h D$ in Economics, Associate Professor of Accounting and Business Consulting,

Simon Kuznets Kharkiv National University of Economics

ORCID ID: 0000-0001-8188-3551

\title{
DEVELOPMENT OF STATE FINANCIAL CONTROL IN THE CONTEXT OF THE FILLING OF THE BUDGET OF UKRAINE
}

\author{
1. В. Дікань, \\ к. е. н., професор кафедри обліку і бізнес-консалтингу, \\ Харківський національний економічний університет імені Семена Кузнеця \\ I. О. Шевченко, \\ к. е. н., доцент кафедри обліку і бізнес-консалтингу, \\ Харківський національний економічний університет імені Семена Кузнеця
}

\section{РОЗВИТОК АЕРЖАВНОГО ФІНАНСОВОГО КОНТРОАЮ В КОНТЕКСТІ НАПОВНЕННЯ} БЮАЖЕТУ УКРАЇНИ

\footnotetext{
The period of reform of the system of public financial control in Ukraine is becoming permanent. Another change in the name of the subject of state financial control instead of the State Audit Office of Ukraine now has another name, namely the Department of Financial Control. The current system of state financial control provides that previous and current financial control over the filling of the budget is carried out by the Ministry of Finance of Ukraine, state tax authorities, customs authorities, and budget expenditures are controlled by the Accounting Chamber of the Verkhovna Rada, the State Treasury and Financial Control. Therefore, further development and reform of the system of public financial control in the context of filling the budget of Ukraine is unresolved. It is these aspects that determined the relevance of the research topic and determined its purpose. The main purpose of this work is a theoretical justification and practical recommendations for further development of public financial control in the context of filling the budget of Ukraine. The article considers topical issues related to the development of public financial control in the context of filling the budget of Ukraine. The theoretical bases of the concept of "development" are considered, the geographical development of the state financial control in the world is defined. Given these characteristics of development, the authors consider it appropriate to outline the socio-economic processes that preceded the emergence of public financial control in Ukraine, presenting the stages of formation and development of public financial control in Ukraine. It is determined that the second and third periods became a significant period of development of state financial control in Ukraine. A detailed overview of the evolution of control is presented in the study. The authors also find that the transformation of the tasks of the Financial Control Department as a body of state financial control indicates a change in priorities in control activities and a change in the ideology of control. The authors emphasize in the study that in modern conditions the role of internal public financial control as a tool to improve the system of internal control of an institution or organization in accordance with the needs arising in the process of their operation is growing. However, the issues of improving the conceptual apparatus of public financial control, substantiation of target characteristics, mechanism, methods of assessing the level and quality of its development in the context of filling the budget of Ukraine remain insufficiently resolved.
} 


\section{ЕКОНОМІЧНА НАУКА}

Період реформи системи державного фінансового контролю в Украйні набуває постійного характеру. Ще одна зміна назви суб'єкта державного фінансового контролю замість,Державної аудиторської служби України має тепер іншу назву, а саме Управління фінансового контролю. Існуюча система державного фінансового контролю передбачає, що попередній та поточний рінансовий контроль за наповненням бюджету здійснюеться Міністерством фінансів Украйни, державними податковими органами, митними органами, а витрачання бюджетних коштів контролюється Рахунковою палатою Верховної Ради Рада Украйни, органи Державного казначейства та Управління фінансового контролю. Тому подальший розвиток та реформування системи державного фінансового контролю в контексті наповнення бюджету України є невирішеним. Саме ці аспекти визначили актуальність теми дослідження та визначили їі призначення. Основна мета даної роботи - теоретичне обгрунтування та практичні рекомендації щодо подальшого розвитку державного фінансового контролю в контексті наповнення бюджету Украйни. Устатті розглядаютьСя актуальні питання, пов 'язані з розвиткомдержавного фінансового контролю в контексті наповнення бюджету України. Розглянуто теоретичні основи поняття "розвиток", визначено географічний розвиток державного фінансового контролю у світі. Враховуючи ці характеристики розвитку, автори вважають за доцільне окреслити соціально-економічні процеси, що передували появі державного фінансового контролю в Украйні, подавши етапи становлення та розвитку державного фінансового контролю в Україні. Визначено, що другий та третій періоди стали значним періодом розвитку державного фінансового контролю в Україні. Детальний огляд еволюції контролю представлений У дослідженні. Автори також виявляють, що трансформація завдань Управління фінансового контролю як органу державного фінансового контролю говорить про зміну пріоритетів У контрольній діяльності та зміну ідеологї контролю. Автори підкреСлюють У дослідженні, що в Сучасних умовах роль внутрішнього державного фінансового контролю як інструменту, який дозволяє вдосконалити СистемУ внУтрішнього контроАю Установи чи організації відповідно до потреб, що виникають у процесі їх функціонування зростає. Однак питання вдосконалення концептуального апарату державного фінансового контролю, обгрунтування цільових характеристик, механізму, методів оцінки рівня та якості його розвиткУв контексті наповнення бюджету України залишаються недостатньо вирішеними.

Key words: development, budget, state financial control, public finances, control system.

Ключові слова: розвиток, бюджет, державний фінансовий контроль, державні фінанси, системаконтролю.

\section{FORMULATION OF THE PROBLEM}

The period of reform of the state financial control system in Ukraine is becoming permanent. Another change in the name of the subject of the state financial control instead of the State Audit Office of Ukraine now has a different name, namely the Office of Financial Control. The existing system of state financial control stipulates that the preliminary and current financial control over the budget filling is exercised by the Ministry of Finance of Ukraine, state tax authorities, customs authorities, and spending of budget funds is controlled by the Accounting Chamber of the Verkhovna Rada of Ukraine, bodies of the State Treasury and the Office of Financial Control. Therefore, the further development and reform of the system of state financial control in the context of filling the budget of Ukraine is unresolved.

\section{ANALYSIS OF RECENT RESEARCH} AND PUBLICATIONS

Many problems of scientists and practitioners have been devoted recently to the problematic issues of the development of the state financial control system. Thus, the prerequisites for development, theoretical foundations, issues of standardization, methodology, typology of state financial control in general are covered in the works of such foreign and domestic scientists as R. Adams, A. Arens,
O.I. Baranovsky, I.V. Basantsov, V.V. Burtsev, A. Visser, V.F. Pikhotsky, L.V.Sukhareva, V.V. Filippova, A.V. Khmelkov, I.Yu. Chumakov, N.V. Shevchenko and many others. However, the issues of improvement of the conceptual apparatus of state financial control, substantiation of target characteristics, mechanism, methods of assessing the level and quality of its development in the context of filling the budget of Ukraine remain insufficiently addressed.

\section{FORMULATING THE GOALS OF THE ARTICLE}

The main purpose of this work is the theoretical substantiation and practical recommendations on the further development of state financial control in the context of filling the budget of Ukraine.

\section{PRESENTING MAIN MATERIAL}

The history of the emergence and development of the system of state financial control is connected with the system of filling the state budget and the socio-economic structure of the country. Therefore, to reveal the evolution of the development of public financial control it is necessary to trace the processes that have formed in the economy of the country at each stage of its development. But above all, in the opinion of the authors it is advisable to decide on the very concept of "development" and the characteristics that reveal it. 


\begin{tabular}{|c|c|c|c|}
\hline \multicolumn{4}{|c|}{ Development of state financial control in foreign countries } \\
\hline France & 1056 & $\longrightarrow$ & $\begin{array}{l}\text { In France, the barons annually publicly read the accounts } \\
\text { of the managers of their possessions before the } \\
\text { controllers }\end{array}$ \\
\hline England & 1130 & $\longrightarrow$ & $\begin{array}{l}\text { The oldest known document that mentions control is the } \\
\text { archives of the Treasury of England and Scotland. The } \\
\text { first legislative act regulating the activity of controllers, } \\
\text { issued in } 1285 \text {. King of England Edward } 1\end{array}$ \\
\hline 1 & & & \\
\hline Europe & $\begin{array}{l}\text { From } \\
\text { the V-IX } \\
\text { centuries }\end{array}$ & & $\begin{array}{l}\text { Many high-profile bankruptcy cases have taken place } \\
\text { that have led to significant demand for the services of a } \\
\text { professional accountant expert }\end{array}$ \\
\hline & & & \\
\hline USA & $\begin{array}{c}\text { From } \\
\text { VI-IX } \\
\text { centuries }\end{array}$ & $\longrightarrow$ & $\begin{array}{l}\text { The financial crisis has necessitated the adoption of a } \\
\text { number of legislative acts to regulate business activity in } \\
\text { the direction of preventing bankruptcy of enterprises }\end{array}$ \\
\hline
\end{tabular}

Fig. 1. Geographic development of public financial control in the world

It is worth noting that development is one of the fundamental philosophical and scientific concepts. It is worth noting that in modern science there are many different definitions of it. Thus, in the Dictionary of the Russian Language SI Burn "development" is defined as "the process of regular change, the transition from one state to another, more perfect; the transition from the old qualitative state to the new, from the simple to the difficult, from the lower to the higher."

In addition, today the term development is used in various fields of knowledge. In development economics most often understand the process of regular changes, the transition from one state to another, more perfect; the transition from the old quality state to the new, from the simple to the difficult, from the lower to the higher.

Formation of state financial control is a long process. The most widespread "control" as a professional term was acquired in France due to certain historical backgrounds. Control (fr. Controle, here contrerole - double list) check, record, monitor anything. The geographical development of the audit in the world is shown in Fig. 1.

Given these characteristics of development, the authors consider it appropriate to outline the socio-economic processes that preceded the emergence of public financial control in Ukraine.

At the same time, according to the authors, the evolution of state control in Ukraine should first of all be considered from the moment of its formation. In this sense, it should be noted that the history of state financial control is inextricably linked to the history of statehood of Ukraine.

However, the most significant period for the development of public financial control in Ukraine was the second and third periods. A detailed review of the evolution of control is presented in Table 1.

The last event, which according to the authors, completed the stage of becoming a state financial control and state financial control in Ukraine was the revision of the said law from 02.12.2012, when its name was changed from "On the State Audit Service in Ukraine" to "On basic principles of the state financial control ". In addition, this edition specified the tasks of the state financial control body. According to the authors, special attention should be paid to the fourth and fifth periods of formation and development of public financial control in Ukraine.

Yes, the fifth period is the beginning of the development of the state financial audit of the implementation of budget programs. This period continues and this time. At the same time, it should be noted that the changes that have taken place in the control of public finances in recent years are due to the European integration policy of Ukraine and the main requirement of the European community - "ensuring transparent and effective management of public finances".

It should be noted that the transformation of the tasks of the Office of Financial Control as a body of state financial control speaks of shifting priorities in control activities and changing the ideology of control (Fig. 2).

It was during this period that the Concept of Development of Public Internal Financial Control was finalized and its term extended until 2017. It should be noted that this Concept was intended to "improve the performance of public sector bodies through the transition from an administrative to a managerial culture, promote the rational use of public resources and strengthen financial discipline; to receive reasonable information about the activities of public sector bodies. " By 2017, an appropriate plan of measures on regulatory, methodological and informationtechnical support, training, organizational and structural changes of individual entities of the public sector of the economy has been developed. According to the author, in 2017, all things being equal, the fourth period of development of the state financial audit of the execution of budget programs should come to a logical end. And starting from 2018, we will have to talk about the fifth period - its sustainable development.

Innovation is the basis for profound changes in the reproduction process. New trends in the economy affect not only tangible but also intangible objects. Changes in the processing of information and knowledge have led to the fact that social wealth is created today mainly through information and intellectual resources. Therefore, the terms "knowledge society", "innovation economy", "information society" have become widely used today. These concepts are combined in the term "knowledge economy" and denote a new socio-economic process, which on the one hand preceded the advent of the state financial audit of the implementation of budget programs, and on the other became the basis for its sustainable development, embodying the type of economy in which knowledge plays leading, and their production is a source of economic growth.

However, it should be noted that, as rightly notes Slobodian YB in the development of the knowledge economy the leading role is played by the state, which 
Table 1. The evolution of control in Ukraine

\begin{tabular}{|c|c|}
\hline Period & Characteristic \\
\hline 1 & 2 \\
\hline $\begin{array}{l}\text { January } 3 \\
1866\end{array}$ & $\begin{array}{l}\text { Control functions throughout Russia were performed by the Office of State Control, } \\
\text { which worked under the Ministry of Finance }\end{array}$ \\
\hline Since March 1917 & $\begin{array}{l}\text { The respective control chambers of state control functioned, and such a structure existed } \\
\text { in Ukraine prior to the establishment of Soviet power. The State Controller of } \\
\text { Emergency Rights and Powers was established on April 2,1918 as a control } \\
\text { department, which was later transformed into the Secretariat of State Control. Later, the } \\
\text { People's Commissariat of State Control of the USSR was formed in Kharkiv }\end{array}$ \\
\hline $\begin{array}{l}\text { January } \\
1924\end{array}$ & $\begin{array}{l}\text { Special body of documentary and subsequent financial control declared the Financial } \\
\text { Control Department (FCU) of the USSR }\end{array}$ \\
\hline November 1926 & $\begin{array}{l}\text { USSR Financial and Control Department reorganized into State Financial Control and } \\
\text { its local authorities }\end{array}$ \\
\hline $1932-1933$ & $\begin{array}{l}\text { The financial and control department of the USSR has become a financial and } \\
\text { budgetary inspection }\end{array}$ \\
\hline $\begin{array}{l}\text { October } \\
1937\end{array}$ & $\begin{array}{l}\text { Special Control and Audit Departments are starting to form within the People's } \\
\text { Commissar of the USSR }\end{array}$ \\
\hline From 1937 to 1956 & $\begin{array}{l}\text { Financial control in Ukraine was carried out by the Control and Audit Department of } \\
\text { the People's Commissariat, later the Ministry of Finance of the USSR. In 1956, the } \\
\text { Audit Department was established within the Ministry of Finance of Ukraine }\end{array}$ \\
\hline $\begin{array}{l}\text { December } \\
1965\end{array}$ & Bodies of party-state control were transformed into bodies of popular control \\
\hline $\begin{array}{l}\text { May } \\
1991\end{array}$ & $\begin{array}{l}\text { Adopted the Law on the USSR Control Chamber, which received the status of the } \\
\text { highest body of financial and economic control }\end{array}$ \\
\hline 1993 & The Law of Ukraine "On the State Control and Audit Service in Ukraine" was adopted \\
\hline 1993 & $\begin{array}{l}\text { The Law of Ukraine "On the Fundamental Principles of Exercising State Financial } \\
\text { Control in Ukraine" was issued }\end{array}$ \\
\hline $\begin{array}{l}\text { August } 27 \\
2000\end{array}$ & $\begin{array}{l}\text { Presidential Decree No. } 1031 \text { "On Measures to Improve the Effectiveness of the } \\
\text { Control and Audit Work" Issued as the Central Executive Body of Ukraine }\end{array}$ \\
\hline $\begin{array}{l}\text { December } 09 \\
2010\end{array}$ & $\begin{array}{l}\text { In accordance with Presidential Decree No. 1085/2010 "On Optimization of the System } \\
\text { of Central Executive Bodies", the Main Control and Audit Department of Ukraine was } \\
\text { reorganized into the State Financial Inspectorate of Ukraine }\end{array}$ \\
\hline $\begin{array}{l}\text { April } 23 \\
2011\end{array}$ & $\begin{array}{l}\text { The State Financial Inspection of Ukraine was established from the Main Audit } \\
\text { Department of Ukraine }\end{array}$ \\
\hline October 28,2015 & $\begin{array}{l}\text { State Audit Service of Ukraine established by the Government resolution on the basis of } \\
\text { the State Financial Inspection }\end{array}$ \\
\hline $\begin{array}{l}\text { December } 17 \\
2016\end{array}$ & $\begin{array}{l}\text { The Cabinet of Ministers has issued an order to create the "Concept of Development of } \\
\text { Public Internal Financial Control for the Period up to 2017" }\end{array}$ \\
\hline February 08,2017 & Strategy for reforming the public finance management system for $2017-2020$ \\
\hline May 10, 2018 & $\begin{array}{l}\text { The Cabinet of Ministers issued an order "On Approving the Concept of Implementing } \\
\text { Public Policy in the Field of Reforming the Public Financial Control System by } 2020 "\end{array}$ \\
\hline December 11, 2019 & $\begin{array}{l}\text { The Government has set up a Financial Control Office in place of the State Audit } \\
\text { Office. The Cabinet of Ministers has created the Office of Financial Control, which will } \\
\text { appear on the basis of the State Audit Office, which inherits its property and functions, } \\
\text { the State Audit Office will also be reduced by } 30 \%\end{array}$ \\
\hline
\end{tabular}

should create an appropriate legal, tax and organizationaleconomic environment, as well as promote changes in the public consciousness, attitudes of citizens to education and knowledge, and popularization of the latter. Therefore, there is a need for mechanisms that would ensure the sustainability of the institutional environment, develop institutions that stabilize and regulate it.
It should be noted that only with the help of effective state control the higher rule of law can guarantee the protection of the financial interests of society, strengthen its confidence in the state power, ensure the achievement of the common goal of the government and society - the welfare of citizens and stability of state power. In today's economic conditions, such control is exercised through a

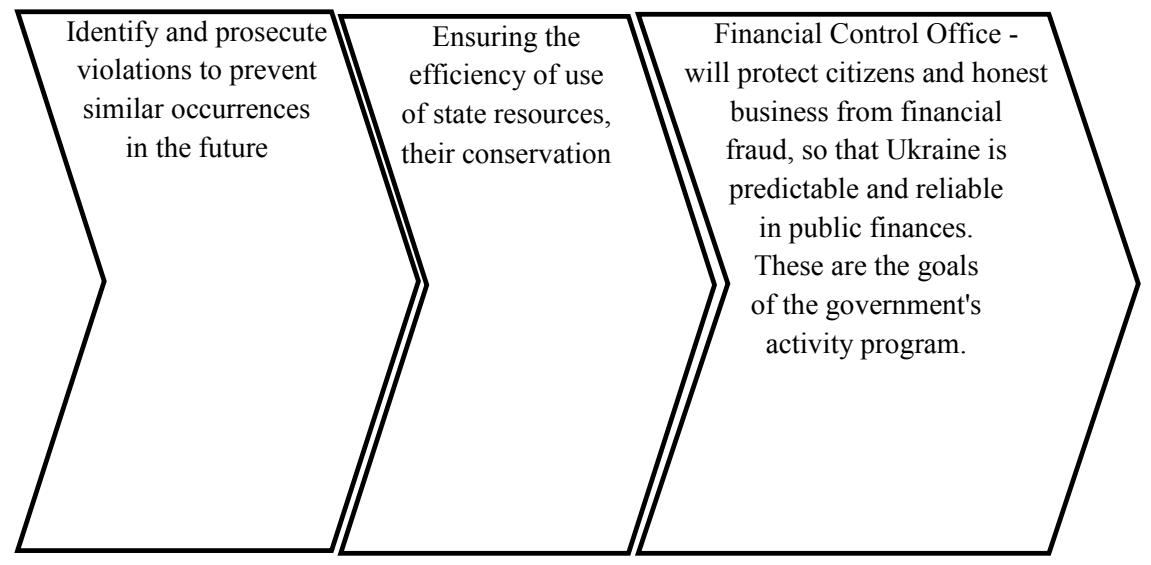

Fig. 2. Transformation of tasks of the state financial control body 
state financial audit of the implementation of budget programs.

At the same time, it should be noted that the reform of the system of state financial control (hereinafter referred to as DFC) involves the revision of such a list of entities as the Office of Financial Control and the Accounting Chamber of Ukraine.

Thus, in accordance with the Budget Code of Ukraine, control over the use of funds of the State Budget of Ukraine on behalf of the Verkhovna Rada of Ukraine shall be exercised by the Accounting Chamber, and the Office of Financial Control will be considered internal control and will be reorganized into separate components depending on the requirements of the Concept of Development of Public Internal Financial Control.

In this context, the role of internal public financial control is increasing as a tool to improve the internal control system of an institution or organization according to the needs that arise in the course of their functioning.

In order to determine the state and outline the tendencies of the development of state internal financial control, it is necessary to study the general state of socioeconomic development of the state, on which the work of the controlling bodies largely depends.

In order to determine the status and outline trends of internal audit development, it is advisable to trace the results of the audit and audit work of the Office of Financial Control of Ukraine and to determine their relationship with the implementation of internal audit in the institution.

Establishing a modern system of public financial control requires taking into account the traditions of the country in the sphere of public administration, state and administrativeterritorial structure and the process of its improvement, in accordance with the general principles and priorities of financial (in particular in the budgetary process) and property policy, as well as in the process of reforms that are held in this area. The process of reforming the system of public financial control requires some time and effort of all its participants.

This should take into account both objective and subjective risk factors that may hinder the process.

At the same time, obstacles or delays in initiating the reform of the public financial control system, driven by risk factors, can lead to intensification of corruption, abuse and financial irregularities and, most importantly, loss of public confidence in the public internal financial control system. In view of the above, and taking into account the principle of the efficiency of the budget system, public financial control should be developed in combination with the implementation of administrative and territorialadministrative reform on a democratic basis.

Among the main ways to improve public financial control in Ukraine are:

1) improvement of the system of state financial control, which will provide: - identification of all components of the control system with an exhaustive list of central executive bodies, which are authorized to exercise financial control in a certain sphere, objects and types of financial control; - establishment of effective functioning of internal financial control in the system of ministries, other central executive bodies and improvement of their interaction with the subjects of state financial control.

2) development of legal framework of activity of subjects of state financial control;

$3)$ improvement of scientific, information, technical and personnel support, which will contribute to: implementation of good domestic and foreign experience in the field of financial control in the practical activity of subjects of state financial control; - development and realization of modern information-technical projects, organization on their basis of operative exchange of information between subjects of state financial control; 145 - to meet the needs of the subjects of the state financial control and control and audit units for training and professional development of personnel.
Public financial control system - a structural construction of public financial control, which consists of a set of subjects and objects of public financial control, types, forms, methods and methods of exercising public financial control aimed at achieving its goal.

The subject of state financial control is the body, its subdivision or their officials, who are empowered by law to exercise public financial control and make management decisions to prosecute financial and financial offenders, including budgetary ones, under administrative and financial responsibility. In their activities, entities of public financial control face a number of problems regarding the effective organization of financial control. Thus, one of the important problems can be considered as duplication of control and audit activities between the bodies entrusted with the exercise of control functions.

To address this group of problems, it is advisable to undertake a number of measures, including: - first, to clearly regulate the functions, rights and responsibilities of financial authorities when agreeing cost estimates and staffing, amending them; - secondly, to introduce new and improve the current standards for the planning of expenditures and the use of budgetary funds and tangible assets; - thirdly, to determine the subject and amount of financial control that should be exercised by the main spending units, departments of departmental control, financial bodies and bodies of the State Treasury, to establish the responsibility of officials for non-performance or improper performance of these functions.

There is also the problem of lack of systematic control, ie compliance of the previous, current and subsequent controls. Today, financial control by the bodies of the Office of Financial Control and its territorial bodies is punitive and educational, but it is not preventive in preventing violations of budgetary discipline and preventing abuse in the financial and budgetary sphere.

In view of this, one of the ways to improve the financial control is to increase the effectiveness of the current control by the Treasury bodies in coordination with the executive authorities and the state tax administration. The effectiveness of preventive rather than follow-up is difficult to overestimate. It would be advisable to involve the bodies of the Office of Financial Control in the exercise of ex-ante control at the stage of forming the estimates of revenues and expenditures of budgetary institutions, or to authorize the financial authorities and bodies of the State Treasury to carry out, in addition to the current, preliminary control over the formation of financial resources of budgetary institutions and organizations.

In the exercise of its control functions, the bodies of the Financial Control Office face the problem of the lack of a unified information control system, that is, access to the databases of other financial supervisory authorities.

In order to establish effective control over all areas of spending of budgetary funds from expenditures for the maintenance of institutions and organizations to their expenditure for social important purposes, it is imperative to establish a systematic exchange of information between all financial and regulatory bodies that ensure the implementation of the budget. That is, a single information base is needed.

In order to solve this problem, it is advisable to computerize the financial control system in Ukraine with access to local and global information transmission networks, which will save time and not disturb these authorities with constant written requests.

The current conditions of economic development of the state require the implementation of new directions and methods of exercising control functions, one of which is the work of analyzing the efficiency of the use of budgetary funds to identify the main factors that lead to inefficient use of financial resources. The level of analytical work at the grassroots level of the State Financial Inspectorate remains low, as a result of which the causes of violations are not 
fully identified and, accordingly, no remedial measures are taken.

This would identify the root causes of the violations and prevent them in the future. In the further analysis of the lower levels of the Office of Financial Control, it is advisable to use the superior and group and summarize them at the level of the State Financial Inspectorate of Ukraine.

Also important are personnel issues of the bodies of the State Financial Inspectorate, where in connection with the economy of budgetary funds, there is an incompleteness of the Inspectorate apparatus, inadequate material incentives for the employees of the institution, which leads to an excessive overload of inspectors, increase staff turnover.

Prospects for improving financial control depend on its quality at all stages and timely response of financial authorities, principal creditors and authorities to the results of further control, ie the revealed facts of misuse and inefficient use of budget funds by taking measures to compensate for illegal expenses, financing and adapting to the regulatory acts governing the budget process.

In order to improve the regulatory framework of public financial control, it is advisable to:

1. To develop and approve the program of legislative activity on improvement of the budget legislation in the sphere of the state financial control, having defined in it specific terms of development and adoption of laws, other legislative acts, to set the terms of its implementation and constant control over the implementation;

2. Adopt the Law of Ukraine "On State Financial Control", which would standardize all the major components of this very important process for the life of the state, clearly distinguish between the bodies of parliamentary and governmental financial control, identify the range of entities of state financial control, hierarchy of bodies that exercise it, the forms of their organization and interaction, etc.;

3. Adopt the Law of Ukraine "On State Control over Compliance with Budget Legislation and Responsibility for Budget Offenses", which should regulate relations in the sphere of state control over compliance with budget legislation, determine the bodies called to exercise such control, their powers, the list of budget violations depending on stages of the budget process;

4. To adopt in the new wording, taking into account the accumulated experience of work of the Accounting Chamber and other organizations, the Law of Ukraine "On the Accounting Chamber", aimed at establishing effective control over the formation and use of state financial, material and other resources, state property (property assets) in Ukraine and the state's liabilities) and achieving its compliance with the Lima Declaration of Guidelines for Financial Control;

5. To hold parliamentary hearings to discuss topical and general problems of organization of effective state financial control in Ukraine and to determine the directions and terms of their resolution;

6. Submit a proposal to the Ministry of Finance of Ukraine on the necessity of introducing the Procedure of bringing to budget institutions, executors of different state passport programs (or other documents), which would clearly define the end result and other conditions for efficient use of budget funds;

7. To develop a methodology for evaluating the effectiveness of control activities and to ensure its use in practical work.

Adoption of the bill "On Financial Control in Ukraine" would complete the creation of the legal basis for the functioning of an integrated system of financial control in Ukraine, would contribute in general to the strengthening of state power, local self-government and stability of the financial system, the establishment of an effective system of state control and the grow th of the state's role in regulating socio-economic development of the state.

At the same time, a number of additional functions should be legally assigned to the Accounting Chamber:
1. financial monitoring (as part of the fight against money laundering);

2. audit of the pre-sale of strategically significant large state-owned objects;

3. Opinion on the right of the Government of Ukraine to allocate funds from the state budget to non-governmental commercial organizations for the account of transfer of their shares in the state ownership;

4. to check the effectiveness of internal financial control, control over all management activities, control over the spending of the state funds in international organizations;

5. methodological guidance, including participation in the implementation of international standards in the practice of public financial control;

6 . introduction of methods of carrying out control measures and criteria of generalization of their results on the basis of audit standards;

7. ensuring the international exchange of ideas and experience within the professional community of state auditors, control over measures that may have financial consequences.

It is important to give the Accounting Chamber the functions of: assessing risks and threats to Ukraine's financial and economic security; preliminary analysis and subsequent control over state programs for ensuring financial and economic security of Ukraine.

In recent years, there has been a debate on the scale of financial control in our country, so it makes sense to generalize the experience of exercising control in foreign countries. Thus, it can be concluded that today the sphere of public financial control in Ukraine needs continuous improvement and reform in order to ensure sustainable development. This is necessary because a single law that regulates the system of public financial control cannot fully cover all the features of conducting public financial control and regulate the spending of public finances in a timely and effective manner. This slows down the allocation of public funds and reduces the performance of the state budget. The use of positive European experience can not only be an important factor in improving the domestic financial control system, but also bring our country closer to the European community.

Мітература:

1. Шевченко І.О., Шевченко Н.В. Реформування системи державного фінансового контролю в умовах євроінтеграції. Науково-практичний економічний журнал "Економічні студії". 2019. № 1 (23). С. 97-101.

2. Розвиток державного фінансового контролю в Україні: монографія Є.М. Романів, С.М. Гончарук, С.В. Приймак, А.Я. Ааниляк; за заг. ред. проф. Романіва Є.М. - Аьвів: Простір. 2015. - М., - 174 с.

3. Аержавний фінансовий контроль: навчальний посібник в схемах і таблицях $\Lambda . B$. Аікань, I.О. Шевченко, Є.В. Аейнеко, А.В. Калінкін. - Харків: ХНЕУ ім. С. Кузнеця, 2019. - 273 с.

4. Микитюк I. Аержавний фінансовий контроль у бюджетній сфері. Світ фінансів. — 2018. 1 (54). - С. 58-69.

References:

1. Shevchenko, I.O. and Shevchenko, N.V (2019), "Reforming the system of state financial control in the context of European integration", Scientific and practical economic journal "Economic Studies", vol. 1 (23), pp. 97-101.

2. Romanov, E.M. Goncharuk, S.M. Prymak, S.V. and Danilyak, L.Ya. (2015), Rozvytok derzhavnoho finansovoho kontroliu v Ukraini [Development of public financial control in Ukraine], Space-M, Lviv, Ukraine.

3. Dikan, L.V. and Shevchenko, I.O. (2019), Derzhavnyj finansovyj kontrol': navchal'nyj posibnyk v skhemakh i tablytsiakh [State financial control: a textbook in diagrams and tables], KhNEU them. S. Kuznets, Kharkiv, Ukraine.

4. Mykytyuk, I. (2018), "State financial control in the budget sphere", Finance World, vol. 1 (54), pp. 58-69.

Стаття надійила до редакиіï 19.05.2020 p. 